\title{
4.12 Викладання гуманітарних дисциплін у технічних закладах вищої освіти України
}

У XXI столітті, коли відбувається перехід до інформаційно розвиненого суспільства, вища освіта набуває особливого значення для розвитку всього людства. Головним завданням кожного вищого навчального закладу, у тому числі і аграрного, є навчання і виховання молодої особистості, яка зможе самостійно вирішувати складні професійні, політичні, економічні, соціальні, культурні та інші проблеми, які з’являються у сучасному суспільстві.

«Педагогіка нас вчить, що спочатку треба поставити завдання, мати певну практику, певні результати. Згодом ми повинні проаналізувати ці результати, просто їх перевірити, з'ясувати що саме вдалося, а що не вдалося. I лише на цій основі пропонувати студентству нові навчальні курси, або приймати якісь глобальні рішення щодо змін у системі освіти. На жаль, усі ми вже звикли працювати у дещо іншій площині, коли спочатку приймаються рішення, а потім педагогічні колективи змушені працювати «під ці рішення»»» [315, с. 24].

Вища освіта в Україні в умовах сьогодення (проблеми в соціальноекономічній сфері, нестабільна політична ситуація, освітянська рерфома, війна на сході України та карантин в умовах пандеміі COVID-19) вимагає від викладачів гуманітарнрх дисциплін для модернізації технічної освіти впровадження інноваційних методів викладання.

Відповідно до Закону України «Про інноваційну діяльність», інновації це новостворені і вдосконалені конкурентоздатні технології, продукція або послуги, a також організаційно-технічні рішення виробничого, адміністративного, комерційного або іншого характеру, що істотно покращують структуру та якість виробництва і соціальної сфери [2, ст.1].

Становлення та розвиток нових технологій і методів у сучасній вищій освіті актуальні, тому є потреба у викладацьких кадрах, які б змогли забезпечити інноваційний підхід до реалізації цих тенденцій під час навчально-виховного процессу. Викладачі отримали можливість створювати і втілювати власні новітні 
методики [317, с. 48]. Але слід зазначити, в умовах реформування системи вищої освіти, зменшення набору студентів, запровадження ЗНО для випускників коледжів та бакалаврів, виникає певна конкуренція між викладачами фахових та суспільно-гуманітарних дисциплін. Усі ці зміни активізували потребу оновлення і вдосконалення освітнього середовища ВНЗ. В Національній доктрині розвитку освіти зазначено, що в Україні повинен забезпечуватися прискорений, випереджальний інноваційний розвиток освіти шляхом оновлення змісту освіти та організації навчально-виховного процесу відповідно до демократичних цінностей, ринкових засад економіки, сучасних науковотехнічних досягнень [318].

Актуальність матеріалу обумовлюється тим, що в умовах модернізації суспільства, глобалізації світу, входження вітчизняної системи освіти у загальносвітовий простір та тими викликами, що стоять перед Україною, без запровадження інноваційних технологій у закладах вищої аграрної освіти та збереження гуманітарних дисциплін, побудова громадянського супільства у нашій державі буде занадто важкою. Оскільки саме суспільно-гуманітарні науки формують особистість студента відповідно до сучасних і реальних вимог нашого суспільства, розвивають його логічне, історико-філософське мислення, навчають політичному і соціально-економічному аналізу процесів, які відбуваються, та розкривають особливості розвитку нашого різномаїтнього світу.

Метою роботи є спроба визначити характерні особливості засобів, форм i методів навчання за допомою інноваційних технологій на прикладі роботи кафедри суспільно гуманітарних наук Таврійського державного агротехнологічного університетету імені Дмитра Моторного, розкрити специфіку їх використання в інтерактивному середовищі вишів України.

Терміни «традиційне навчання» та «інноваційне навчання» запропоновані групою вчених у доповіді Римському клубу (1978), який звернув увагу світової наукової громадськості на неадекватність принципів традиційного навчання

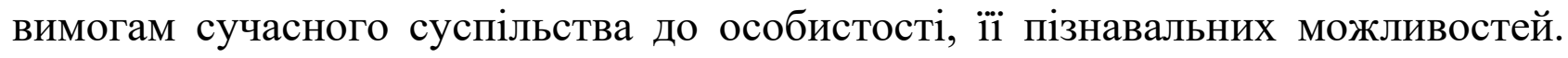
Інноваційне навчання орієнтоване на формування готовності особистості до 
динамічних змін у соціумі за рахунок розвитку здібностей до творчості, різноманітних форм мислення, а також здатності до співробітництва з іншими людьми. Головними недоліками традиційної системи освіти є породжені нею невміння і небажання дітей вчитися, несформованість цілісного ставлення до власного розвитку та освіти. Подолання кризи сучасної освіти можливе завдяки формування принципово нової системи освіти [319, с.28].

Інновація освіти - цілеспрямований процес часткових змін, що ведуть до модифікації мети, змісту, методів, форм навчання й виховання, адаптації процесу навчання до нових вимог. Інновації у вищій школі передбачають: вивчення, узагальнення та поширення кращого вітчизняного, європейського та світового досвіду в цій сфері; організація і проведення конференцій, семінарів, круглих столів, тренінгових курсів 3 інноваційних методик викладання гуманітарних дисциплін у аграрному ВНЗ; застосуванні кредитно-модульної системи організації навчального процесу з рейтинговою оцінкою знань студентів. Це $є$ запорукою підвищення якості навчання та стимулювання самостійної роботи студенів [320, с. 35].

Для більш результативного навчання виправдане застосування принципу наочності разом з викладанням матеріалів леції за допомогою комп'ютера, проектора, інтерактивної дошки, телевізорів $з$ великою діогоналлю тощо. Таким чином викладач оптимізує та урізномаїтнює процесс гуманітарних дисциплін.

Але існують перепони пов'язані із застосуванням інноваційних технологій, які мають об’єктивний та суб’єктивний характер. До першого типу віносяться: недостатність правового забезпечення або часті зміни у змісті навчального процесу; неготовність викладачів перейти на нові форми і методи викладання; відсутність організаційних осередків інновацій; матеріальнотехнічні проблеми. До другого типу: - пасивність викладача у використанні нових технологій, через постійну зміну «правил гри».

Викладач вважається готовий до інноваційної діяльності за таких умов: внутрішньо визнав значимість змін; він готовий до розв'язання нестардатних 
ситуацій у навчальному процесі; ситуація в колективі та установі сприятливі до запровадження інновацій та підримує викладача-новатора.

На сьогодні педагогічна наука розрізняє кілька видив традиційних технологій: предметно орієнтована (головна мета навчання - засвоєння матеріалу); особисто орієнтована (від студента, головне не засвоєння матеріалу, а розвиток його особистості); партнерська (викладач дбає як за засвоєння навчального матеріалу, так і за розвиток особистості студента).

Але криза освіти у сучасному світі викликали до життя нові освітні технології, пов'язані 3 неможливістю опанувати існуючий обсяг знань, зростанням вимог до професійних навичок, що виявляє великі проблеми у передачі знань традиційнми формами навчанн. Новою технологією організації навчального процесу є технологія ситуаційного навчання (кейс-метод). Його сутність можуть ілюструвати наступні положення. По-перше, мета навчання відрізняється від класичної схеми - навчити, дати єдино «правильні», раз і назавжди визначені знання, вміння та навички. Навчальний процес орієнтований на усвідомлення не єдиної, а багатьох істин. У технічному ЗВО кейс-метод можна застосувати для вивчення дисциплін, істина в яких плюралістична: у філософії, педагогіці, психології, історії тощо. По-друге, кейс-методу, на відміну від традиційних технологій, властивий демократичний характер процесу одержання знань. Студент є рівноправним із іншими учасниками обговорення проблеми, у тому числі з викладачем [321, с.100]. Головним у навчанні $є$ не оволодіння готовими знаннями, а їх вироблення в процесі співтворчості студента й викладача.

Але, на жаль, в Україні через значні соціально-економічні проблеми застосування цієї технології поки неможливе. Традиційні форми організації навчального процессу дають нам такі показники за умов пассивного навчання (лекція - 5\%, читання - 10\%), а найбільші - активного та інтерактивного (дискусійні групи - 50\%, практика через дію - 75\%, навчання інших чи негайне застосування - 90\%) [322, с.101]. Це, безперечно, середньостатистичні дані, і в конкретних випадках результати можуть бути дещо іншими, але в середньому 
таку закономірність може простежити кожен педагог. В даний час немає чіткого поділу між активними та інтерактивними методами навчання, одні і ті ж методи можуть ставитися різними експертами і до активних, і до інтерактивних [323].

Сучасною формою активних методів навчання виступають інтерактивні методи навчання. Інтерактивні методи навчання пов'язані з більш тісною взаємодією студентів не тільки з викладачем, але і між собою. Викладач виконує роль організатора, помічника, створюючи новий формат проведення занять.

Кафедра суспільн-гуманітарних наук була створена 26 серпня 2015 року шляхом обєднання кафедр українознавства та філософії і соціології. (Наказ №374-ОД від 26.08.15). Сьогодні кафедра налічує 13 співробітників, серед яких 2 професори, 1 доктор політичних наук, 1 ддоктор філологічних наук 10 кандидатів наук: історичних, філологічних, педагогічних, філософських, соціологічних; 4 ст.викладача та 2 старших лаборанта. Очолює кафедру кандидат філологічних наук, доцент Максимець Оксана Миколаївна.

Специфікою кафедри є викладання широкого спектру дисциплін для студентів усіх факультетів університету: «Історія України та історія української культури», «Історія науки і техніки», «Українська мова за професійним спрямуванням», «Культура наукової мови», «Психологія», «Політологія», «Соціологія», «Етика та естетика», «Інтелектуальна власність», «Філософські проблеми наукового пізнання», «Філософія науки та інноваційного розвитку», «Психологія і педагогіка в вищій школі», «Педагогіка».

Викладачі кафедри навчальну роботу спрямовують на активізацію інтелектуально-духовного потенціалу молоді, вдосконалення iї мовної культури, поглиблення знань з україністики, філософії, правознавства, психології та педагогіки, використовуючи сучасні методи та прийоми викладання. Важливе значення серед різних форм проведення занять завжди мала і має лекція. До числа найбільш часто використовуваних інтерактивних лекцій можна віднести: проблемну лекцію, лекцію-провокацію, лекціювізуалізацію, лекцію прес-конференцію, лекцію-бесіду і лекцію-дискусію. При 
навчанні студентів не можна повністю відмовитися від класичних лекцій, необхідно поступово доповнювати їх нетрадиційними формами, вносити в них інноваційні елементи, орієнтуючись на студентську аудиторію.

Останнім часом серед викладачів кафедри СГН популярності набувають інтерактивні лекційні та практичні заняття. В ході таких занять у студентів формуються вміння формулювання своєї позиції, постановки і рішення задач, відстоювання своєї точки зору, навички проведення дискусії. Найпопулярнішими серед викладачів при проведенні інтерактивних занять є такі методи: навчальна дискусія, «мозковий штурм», «круглий стіл», ділова гра які застосовуються на заняттях 3 історичних, філософських, психологічних та філологічних дисциплін.

Ще одним іноваційним методом організації навчальної діяльності викладачів кафедри є використання дистанційної освіти, яка забезпечує доставку інформації в інтерактивному режимі за допомогою використання інформаційнокомунікаційних технологій (система Moodle) від викладачів до студентів. Дистанційне навчання зробило справжню революцію в освітньому та інформаційному процесах. Онлайн-курси різних дисциплін кафедри СГН доступні кожному студенту, який має доступ до мережі Інтернет та навчального порталу ТДАТУ. Портал наповнений різноманітними пропозиціями онлайнкурсів, тому студенту лишається тільки обрати курс собі відповідно навчального плану свого курсу та спеціальності. Особливо актуальним стало використання дистанційної освіти під час карантину в умовах пандемії COVID-19.

Метою самостійної роботи є закріплення знань, формування умінь i навичок, розширення інтересу до дослідницької діяльності, підвищення рівня підготовки студента. в сучасних умовах великого значення набуває використання інтерактивних форм самостійної роботи студентів. Наприклад, завдання для самостійної роботи студентів можуть бути спрямовані на підготовку презентацій з окремих проблемних питань дисциплін кафедри, робота з базою тестів для навчання і для контролю знань, Провідні фахівці кафедри, маючи на меті залучити студентів до цілеспрямованої наукової 
діяльності, керують роботою наукових студентських гуртків, учасники яких оволодівають необхідними навичками дослідницької роботи.

Одним із пріоритетів діяльності кафедри $є$ виховна робота. Адже утвердження української національної ідеї і розбудова на іiї основі нашої держави вимагає висококваліфікованих спеціалістів, з високими моральними якостями, розвиненими почуттями патріотизму, громадянської та національної гідності, активної життєвої позиції в процесі державотворення. Підготовка таких спеціалістів здійснюється на основі вимог державної концепції національного виховання та концепції виховання, розробленої в університеті, 3 урахуванням етнічних, соціальних і духовних особливостей студентського колективу. Зусилля викладачів кафедри спрямовуються на те, щоб кожна лекція, практичне чи семінарське заняття мали виховну спрямованість, а виховання студентів проводилося не лише на основі розгляду тих чи інших тем, питань, прикладів та фактів, але й особистісної оцінки різних проблем.

Отже, використання інноваційних методик у навчальному процесі ВН3, зокрема при вивчення гуманітарних дисциплін, створює умови для ефективної самореалізації особистості майбутнього фахівця аграрного профілю. Значною мірою це залежить від педагогічної майстерності викладача гуманітарних дисциплін, від прояву його майстерності, бажання оволодівати сучасними освітніми технологіями та готовності студента до цих інновацій і в навчальновиховному процесі. 